\title{
Differential Expression of Key Floral Initiation Genes in Response to Plant Growth Regulator Application and Alternate Bearing in Pecan
}

\author{
Marisa Y. Thompson \\ Department of Plant and Environmental Sciences, New Mexico State University, Box 30003 MSC \\ 3Q, Las Cruces, NM 88003 \\ Jennifer J. Randall \\ Department of Entomology, Plant Pathology, and Weed Science, New Mexico State University, \\ Box 30003 MSC 3BE, Las Cruces, NM 88003 \\ Dawn VanLeeuwen
Department of Economics, Applied Statistics, and International Business, New Mexico State
University, Box 30001 MSC 3CQ, Las Cruces, NM 88003 \\ Richard J. Heerema \\ Department of Plant and Environmental Sciences, New Mexico State University, Box 30003 MSC \\ $3 Q$, Las Cruces, NM 88003
}

\begin{abstract}
Additional Index words. apetala1, bioregulators, Carya illinoinensis, ethephon, gibberellic acid, phytohormones
Abstract. Regarding pecan (Carya illinoinensis), alternate bearing, which is a biennial fluctuation of crop yield, is a major hindrance for the pecan industry. Little is known about the internal cues that trigger pecan shoots to become reproductive. This 2-year study approached the mysteries of alternate bearing of pecan by determining whether pecan homologs of three genes known to control floral initiation in other species are expressed differently at various times of the growing season or in distinct plant tissues, and whether expression of these genes can be manipulated by plant growth regulator (PGR) application when compared with an untreated control group. The flowering genes of interest were pecan homologs of leafy (CpLFY), apetala1 (CpAP1), and flowering locus $t(C p F T)$. During year 1 (2014), PGRs ethephon and gibberellin $\mathbf{G A}_{3}$ were applied at the shoot level 1 week before each of three tissue sampling dates (13 June, 3 July, 29 July). During the following year (2015), two more PGRs were added to the study [a second double rate (2X) of gibberellin $\mathrm{GA}_{3}$ and ethylene inhibitor aminoethoxyvinylglycine (AVG)] for a total of four PGRs (applied on 10 June, 1 July, and 23 July) plus the untreated control. Experimental leaf and bud tissues were sampled from fruiting and nonfruiting shoots on mature 'Western' pecan trees and analyzed separately. Normalized expression levels of $C p L F Y$ and $C p A P 1$ were significantly higher in buds than in leaves. Normalized expression of $C p L F Y$ in bud tissues differed statistically based on the sampling date in 2014, with the earliest date (13 June) having higher expression than the two later dates that year. In 2015, a treatment $\times$ date interaction revealed that, compared with the untreated control, $C p L F Y$ expression was significantly lower in shoots treated with both gibberellin $\mathbf{G A}_{3}$ dosages on 1 July. A few weeks later (23 July), $C p L F Y$ expression was lower in the $2 \mathrm{X} \mathrm{GA}_{3}$ treatment group and higher in samples treated with AVG. In 2014, CpAP1 expression in buds was significant, with a treatment $\times$ date interaction in which ethephon increased $C p A P 1$ expression, but only on one date (29 July). In 2015, bud $C p A P 1$ expression was significantly higher in fruiting than in nonfruiting shoots; however, again, only on one date. The results reveal differential expression of these key flowering genes based on tissue type, sampling date, and fruiting status of the shoot and PGR treatment. Results suggest that more research of the effects of PGRs is necessary for understanding the flowering behavior of pecan and mitigating the intensity of alternate bearing.
\end{abstract}

Alternate bearing $(\mathrm{AB})$ is the most important horticultural problem for the pecan (Carya illinoinensis) industry (Wood, 2003). Alternate bearing in perennial tree crops comprises a propensity for "on" years of high fruit yield interspersed with "off" years of lower yield, with some interannual alterations. Fluctuations in pecan yields are often associated with variations in nut quality, and higher crop loads are likely to result in smaller, lower-valued nuts and vice versa (Conner and Worley, 2000). Inconsistencies in yields from year to year tend to be synchronized not only from tree to tree within an orchard but also between orchards, and even across the entire United States pecan growing belt (U.S. Department of Agriculture, 2017). Synchronized AB impedes the pecan industry by disrupting growers' budgets, creating unbalanced supply and demand levels for labor and equipment, and influencing product pricing and availability.

Flowering behavior of pecan is complicated by $\mathrm{AB}$ and other intricacies, including the temporal separation between floral initiation (occurring in the year before flowering) and floral differentiation (occurring just before budbreak in late winter or early spring) (Amling, 1983; Amling and Amling, 1983; Wood, 2011b). Additionally, pecans are a monoecious, heterodichogamous species, meaning that each tree houses both pistillate and staminate arrangements of imperfect flowers that become active at different times in the season and comprise two types: 
protogynous (type II), which include pistillate flowers that are receptive to pollen before staminate flowers on the same tree dehisce, and protandrous (type I), which have staminate flowers that dehisce before pistillate flowers are receptive to pollen (Woodroof, 1930; Woodroof and Woodroof, 1926). Another level of pecan flowering complexity involves bud anatomy before budbreak, whereby each bud contains two sets of primordial staminate inflorescences (i.e., catkins) and a primordial shoot that may be either fruiting or nonfruiting (vegetative) (Herrera, 1999).

Identifying the location and timing of molecular floral initiation signals within pecan buds and leaves could be the key to understanding $\mathrm{AB}$ and eventual mitigation of $\mathrm{AB}$ in pecan because it has been the key to understanding other important tree crops with AB tendencies. Research of the model plant Arabidopsis thaliana has resulted in major advancements that have led to the isolation and characterization of more than 180 genes involved in flowering. These include apetalal (AP1), constans (CO), flowering locus $t(F T)$, leafy (LFY), and suppressor of overexpression of constans 1 (SOC1) (An et al., 2004; Fornara et al., 2010; He and Amasino, 2005).

Further studies of flowering pathways in woody perennial species, such as apple (Malus $\times$ domestica), citrus (Citrus sp.), chinese hickory (Carya cathayensis), pear (Pyrus sp.), pecan, and poplar (Populus sp.) have confirmed conservation of several $A$. thaliana flowering genes (Endo et al., 2005; Flachowsky et al., 2012; Guitton et al., 2012; Hsu et al., 2011; Kotoda et al., 2010; Liu et al., 2013; Matsuda et al., 2009; Mimida et al., 2011; Shalom et al., 2012; Wang et al., 2012, 2019). Some flowering genes, like FT, are expressed predominantly in leaf tissues, and the mobile FT protein is translocated via the phloem to the shoot apical meristem (SAM), where it promotes flowering (Abe et al., 2005; Takada and Goto, 2003; Yamaguchi et al., 2005). LFY, AP1, and others are primarily expressed in the SAM (Abe et al., 2005; Blázquez et al., 1997). Preliminary $C p L F Y$ expression data of leaf tissues of untreated fruiting and nonfruiting shoots from 'Wichita' pecan trees indicated that $C p L F Y$ was active in fruiting shoots in July, possibly during floral initiation for the next season, and deserving of further study (Randall et al., 2015; Rascon, 2014). Triggers for the expression of these key genes may involve phytohormone levels, which fluctuate based on both external (i.e., environmental) and internal (i.e., endogenous) cues (Abe et al., 2005; An et al., 2004; Glover, 2008; Michaels and Amasino, 2000).

Exogenous applications of PGRs can potentially be used as tools for modifying flowering behavior and mitigating $\mathrm{AB}$ in pecan, as well as in other species such as apple and citrus (Meland

Received for publication 19 June 2020. Accepted for publication 15 Mar. 2021.

Published online 3 May 2021.

We thank Christian Barraza, Kimberly Cervantes, Greg Daviet, Paul Lambert, Jacob Lilley, Dave Lowry, Esteban Morales, Sara Moran, Dr. Tesneem Nusayr, Dr. Hormat Rhein, Cody Runyan, Frank Sholedice, Dr. Rio Stamler, and the crew at the NMSU Leyendecker Research Center for their help in the field and with the manuscript. We acknowledge the assistance of the technical staff of the collaborators and partial funding for this project provided by the U.S. Department of Agriculture Specialty Crop Initiative, New Mexico Specialty Crop Block Grants, administered by the New Mexico Department of Agriculture (12-25-B-1686), as well as the NMSU Agricultural Experiment Station.

This work is based on part of a dissertation in partial fulfillment of the requirements for a $\mathrm{PhD}$ degree at New Mexico State University (NMSU).

M.Y.T. is the corresponding author. E-mail: risi@nmsu.edu.

This is an open access article distributed under the CC BY-NC-ND license (https://creativecommons.org/licenses/by-nc-nd/4.0/). and Kaiser, 2011; Muñoz-Fambuena et al., 2012; Thompson et al., 2019; Wood, 2011a, 2011b; Wood et al., 2009). For multiple fruit tree species, individual shoots have been shown to function independently with respect to $\mathrm{AB}$, also known as branch autonomy (Chan and Cain, 1967; Monselise and Goldschmidt, 1982; Rascon, 2014; Rohla et al., 2007; Tombesi et al., 2011; Weinbaum et al., 2001; Wood, 1991, 2011b). Plant growth regulators applied to pecan shoots affect return bloom differently, depending on whether the shoots were nonfruiting or fruiting during the treatment year (Thompson et al., 2019; Wood, 1991, $2011 \mathrm{~b}$ ). For example, in a parallel study of the same shoots as those described in the current study, $100 \mathrm{mg} \cdot \mathrm{L}^{-1}$ gibberellin $\mathrm{GA}_{3}$ treatment on fruiting shoots increased the number of flowers during the following year by $125 \%$ compared with the control shoots, but nonfruiting shoots treated with the same $\mathrm{GA}_{3}$ concentration had a $52 \%$ reduction in return bloom (Thompson et al., 2019). Notably, in the parallel study, the number of flowers per new shoot (one of several return bloom parameters studied) was reduced in nonfruiting shoots by all PGRs, including ethephon, both rates of gibberellin $\mathrm{GA}_{3}$, and aminoethoxyvinylglycine (AVG), as much as $93.3 \%$ for AVG. However, connections between the effects of PGR applications and expression levels of genes likely to be involved with flowering have not been previously examined in pecan. The objective of this study was to identify current season differences in the expression of pecan homologs of the flowering genes $L F Y$ ( $C p L F Y), A P 1$ $(C p A P 1)$, and $F T(C p F T)$ in leaf and bud tissues selected from fruiting and nonfruiting shoots on 'Western' (synonym 'Western Schley') pecan trees after exogenous PGR applications.

\section{Materials and Methods}

EXPERIMENTAL LOCATION AND DESIGN. The experimental site was a commercially managed orchard consisting mainly of mature 'Western' and 'Ideal' pecan trees $(\approx 45$ years old) located in the Mesilla Valley, NM (lat. $32^{\circ} 14^{\prime} 26^{\prime \prime} \mathrm{N}$, long. $106^{\circ} 46^{\prime} 20^{\prime \prime} \mathrm{W}$; elevation $1181 \mathrm{~m})$. Environmental data collected at a nearby weather station on the New Mexico State University main campus reported $163,210,320$, and $215 \mathrm{~mm}$ of annual rainfall during the years 2013, 2014, 2015, and 2016, respectively (New Mexico State Climate Center, 2017). Mature orchard AB intensity (yearto-year fluctuations in crop load) in the experimental orchard was high (as high as $751 \mathrm{~kg} \cdot \mathrm{ha}^{-1}$ ) and the average yield was 2845.85 $\mathrm{kg} \cdot \mathrm{ha}^{-1}$. According to commercial production records of the 12.5-ha area surrounding the six mature 'Western' experimental trees, yields were $2478.2,3158.6,2517.4$, and $3229.2 \mathrm{~kg} \cdot \mathrm{ha}^{-1}$ in 2013, 2014, 2015, and 2016, respectively. The orchard plot was flood-irrigated on schedules based on water availability, rainfall, temperature, and tree growth stage at the discretion of the orchard manager. Insecticide application, fertilization, and groundcover were all controlled by the orchard management.

Six 'Western' pecan trees from a single irrigation plot were selected for this study. Structured as a randomized complete block experiment, each tree comprised a single block, with individual shoots representing experimental units (6 and 10 shoots per tree in 2014 and 2015, respectively).

ExOGENOUS APPLICATION OF PLANT GROWTH REgULATOR TREATMENTS. In a parallel study focused on PGRs and their effects on return bloom, PGR applications were performed three times each year in the 2014 and 2015 growing seasons at $\approx 3,6$, and 9 weeks after full bloom for current season individual 
shoots; subsequent season return bloom parameters from the same treated shoots were reported during the 2015 to 2016 growing seasons (Thompson et al., 2019). Previous PGR research of $\mathrm{AB}$ of pecan determined that pistillate flower initiation is likely to occur in this timespan after full bloom (Wood, 2011b). For this current study, whole leaf and bud tissues were collected from treated shoots $\approx 1$ week after each PGR application for a total of three collection dates per season.

As described by Thompson et al. (2019), three treatments were applied to both fruiting and nonfruiting (vegetative) shoot populations in 2014. Treatments were 1) untreated control; distilled water plus surfactant (Kinetic; Helena Chemical Co., Collierville, TN), 2) $100 \mathrm{mg} \cdot \mathrm{L}^{-1}$ ethephon (Ethrel; Bayer CropScience, Calgary, $\mathrm{AB}$, Canada) plus surfactant, and 3) $50 \mathrm{mg} \cdot \mathrm{L}^{-1} \mathrm{GA}_{3}$ (ProGibb; Valent BioSciences, Libertyville, IL) plus surfactant. In 2015, two additional treatments were added to the experiment for a total of five treatments, which were also applied to both fruiting and nonfruiting shoot populations. Additional treatments were 4) 100 $\mathrm{mg} \cdot \mathrm{L}^{-1} \mathrm{GA}_{3}$ at double rate (ProGibb; Valent BioSciences) plus surfactant, and 5) $0.88 \mathrm{~g} \cdot \mathrm{L}^{-1}$ ethylene inhibitor AVG (ReTain; Valent BioSciences) plus surfactant. Treatment applications were performed using handheld bottle sprayers and plastic funnelshaped collars to reduce the possibility of chemical drift during application. Treatment applications were performed on three dates in 2014 and three dates in 2015 (Table 1). Shoot selection was performed as described in the parallel study (Thompson et al., 2019).

Tissue SAMPLing. Approximately 1 week after the application of PGRs (Table 1), a whole compound leaf from the middle of the shoot and the associated bud were sampled from one nonfruiting shoot and one fruiting shoot per treatment group in each tree on a total of three sample dates; 108 total shoots were sampled from this site in 2014 and 180 shoots were sampled from this site in 2015. Tissues were placed in conical tubes and immediately frozen in liquid nitrogen. The samples were maintained at $-80^{\circ} \mathrm{C}$ until further processing.

GeNe EXPRESSION ANALYSES OF TISSUES. Leaf and bud tissues were homogenized separately with a mortar and pestle using liquid nitrogen, and $\approx 100 \mathrm{mg}$ of ground tissue was used for small-scale RNA isolation with Purelink Plant RNA Reagent (Invitrogen; Thermo Fisher Scientific, Waltham, MA) according to the manufacturer's instructions. RNA from each sample was treated with deoxyribonuclease I (DNase I) (Amplification Grade; Invitrogen) to remove any contaminant DNA. Each reaction tube for DNase treatment consisted of $15.0 \mu \mathrm{L}$ of RNA, $2.0 \mu \mathrm{L}$ of 10X DNase Buffer, $1.0 \mu \mathrm{L}$ of DNase I, and sterile water to bring the total reaction volume to 20.0 $\mu \mathrm{L}$. The reaction was incubated at room temperature for $15 \mathrm{~min}$, followed by the addition of $1.0 \mu \mathrm{L}$ of $25 \mathrm{~mm}$ EDTA solution and an incubation NM. period of $10 \mathrm{~min}$ at $65^{\circ} \mathrm{C}$. The DNase-treated RNA preparations were stored at $-80^{\circ} \mathrm{C}$.

DNase-treated RNA was quantified using a spectrophotometer (NanoDrop 1000; Thermo Fisher Scientific). Complementary DNA (cDNA) was synthesized using a SuperScript ${ }^{\mathrm{TM}}$ IV FirstStrand Synthesis System (Invitrogen). The initial reaction consisted of $20 \mathrm{ng}$ of DNase-treated RNA, $1.0 \mu \mathrm{L}$ of $50 \mu \mathrm{M}$ oligo $\mathrm{dT}$ primer, $1.0 \mu \mathrm{L}$ of $10 \mathrm{~mm} \mathrm{dNTP}$ mix, and sterile water to bring the volume to $14.0 \mu \mathrm{L}$. The reaction was incubated at $65^{\circ} \mathrm{C}$ for 5 min, placed on ice for at least $1 \mathrm{~min}$, and vortexed for $3 \mathrm{~s}$. The secondary reaction included the addition of $4.0 \mu \mathrm{L}$ of $5 \mathrm{X}$ SuperScript ${ }^{\mathrm{TM}}$ IV Reverse Transcriptase Reaction buffer (Invitrogen), $1.0 \mu \mathrm{L}$ of $100 \mathrm{~mm}$ DTT, and $1.0 \mu \mathrm{L}$ of SuperScript ${ }^{\mathrm{TM}}$ IV Reverse Transcriptase (Invitrogen). The total reaction volume was $20.0 \mu \mathrm{L}$; it was incubated at $52.5^{\circ} \mathrm{C}$ for $10 \mathrm{~min}$, followed by an extension of $80^{\circ} \mathrm{C}$ for $10 \mathrm{~min}$. The cDNA was stored at $-20^{\circ} \mathrm{C}$.

Gene-specific primers were designed for actin and $L F Y$ using nucleotide alignments of chinese hickory, walnut (Juglans regia), apple, and poplar with Geneious (version 5.5.7; Biomatters, Auckland, New Zealand). The pecan homologs CPAP1 and CpFT were identified using the pecan draft genome 87 MX 3.11 (Jenkins et al., 2015) using Geneious version 9.1 software (Kearse et al., 2012) (Table 2). Primer probe assays were synthesized by Integrated DNA Technologies (Coralville, IA), each with a unique fluorophore (fluorescent reporter dye), and included a quencher, which allowed for multiplexing with several target genes that can be amplified and quantified in a single reaction tube during quantitative real-time polymerase chain

Table 1. Dates of plant growth regulator (PGR) treatment applications (untreated control, ethephon, and gibberellic acid $\mathrm{GA}_{3}$ in 2014, and an additional double $\mathrm{GA}_{3}$ rate and aminoethoxyvinylglycine in 2015$)$ and tissue collection $(\approx 1$ week after PGR treatments were applied) in 2014 and 2015. Study was conducted in a mature 'Western' pecan orchard in Las Cruces,

\begin{tabular}{lcccc}
\hline \multicolumn{2}{c}{2014} & & \multicolumn{2}{c}{2015} \\
\cline { 1 - 2 } PGR application dates & Tissue collection dates & & PGR application dates & Tissue collection dates \\
\hline 6 June & 13 June & & 4 June & 10 June \\
27 June & 3 July & & 24 June & 1 July \\
18 July & 29 July & & 16 July & 23 July \\
\hline
\end{tabular}

Table 2. Primers and probes used for quantitative real-time polymerase chain reaction analysis of target gene expression in pecan bud and leaf tissue samples. Pecan homologs of four target genes included the reference gene actin $(C P A C T I N)$ and three genes of interest: leafy $(C p L F Y)$, apetalal (CpAPl), and flowering locus $t(C p F T)$.

\begin{tabular}{lll}
\hline Target gene & Assay form & \multicolumn{1}{c}{ Sequence } \\
\hline CpACTIN & Probe & $5^{\prime}$-/5HEX/TGGAAGAGA/ZEN/ACTTCTGGGCAACGG/3IABkFQ/-3' \\
& Primer 1 & $5^{\prime}$-TTGTATGTGGTCTCGTGGATTC-3' \\
& Primer 2 & $5^{\prime}$-ATCACAATTGGAGCTGAGAGG-3' \\
CpLFY & Probe & $5^{\prime}$-/56-FAM/AGCAGTGCC/ZEN/GTGATTTCTTGATCCA/3IABkFQ/-3' \\
& Primer 1 & $5^{\prime}$-CGCTCCTTCGCTATGTTCTG-3' \\
& Primer 2 & $5^{\prime}$-CGATTACCTCTTCCATCTCTACG-3' \\
CpAP1 & Probe & $5^{\prime}$-/5TEX615/TGCGCTTTCTTCAGCAAACCAGAC/3IAbRQSp/-3' \\
& Primer 1 & $5^{\prime}$-AGAGGATCGAGAACAAGATCAA-3' \\
& Primer 2 & $5^{\prime}$-GCATCACAAAGCACAGAGAT-3' \\
CpFT & Probe & $5^{\prime}$-/5Cy5/AGCTCAAGCCGTCTCATGTTGTCA/3IAbRQSp/-3' \\
& Primer 1 & $5^{\prime}$-CTCTGAGGGTCACTTACAACAA-3' \\
& Primer 2 & $5^{\prime}$-GTCATCACCGCCTACATCAA-3' \\
\hline
\end{tabular}


reactions (qRT-PCR) (Table 3). Assays for each sample were performed in triplicate using $\mathrm{iQ}^{\mathrm{TM}}$ Multiplex Powermix (BioRad Laboratories, Hercules, CA) with $20 \mathrm{ng}(1.0 \mu \mathrm{L})$ cDNA, $1 \mathrm{X}$ concentration of each probe, and sterile water in a final volume of $10.0 \mu \mathrm{L}$. Genomic pecan DNA was used as a positive control, and three negative extraction controls were included in each reaction plate. The CFX96 Touch Real-Time PCR Detection System (Bio-Rad Laboratories) was used, and the qRT-PCR program comprised $95^{\circ} \mathrm{C}$ for $2.5 \mathrm{~min}$, followed by 39 cycles of $95^{\circ} \mathrm{C}$ for $15 \mathrm{~s}$ and $60^{\circ} \mathrm{C}$ for $60 \mathrm{~s}$. Each qRT-PCR result was regarded as positive for any cycle threshold value less than 35.0.

Starting quantities (SQ) were calculated by Bio-Rad Laboratories software using the CFX Touch Real-Time PCR Detection System and based on standard curves of genomic pecan DNA (gDNA) dilution series performed in triplicate on each plate. These served as the estimates of the initial amounts of each of the target genes in each individual well of a 96-well plate. The standard curves were individual threshold cycles plotted against the log of the gDNA SQ at each dilution level. For each sample, the average target gene SQ from three technical replicates performed within each plate were normalized to the reference gene (actin) SQ. Therefore, normalized gene expression was calculated as the ratio of average target gene SQ to average reference gene SQ.

DATA ANALYsis. For each year, gene expression variables with sufficient nonzero observations (at least $50 \%$ ) were analyzed using a mixed model with fixed effects for treatment, fruiting status, date, and all interactions among these three factors. The model incorporated random effects corresponding to the blocking factor, tree, and tree by date. Fisher's least significant difference was used for post hoc pairwise comparisons applied to assess simple effects corresponding to the highest order significant effect.

Paired leaf and bud normalized gene expression values were compared using the sign test (Ramsey and Schafer, 2002). Analyses were performed with SAS software (version 9.4; SAS Institute, Cary, NC). Significance was defined as $\alpha=0.05$ for all analyses; however, differences were acknowledged as "marginally significant" at $\alpha=0.10$.

For all analyses, the outlier strategy was used; outliers were defined as data points producing studentized residuals with magnitudes greater than three (Ramsey and Schafer, 2002). That is, if re-analysis with outliers removed produced the same pattern of significance, then only the analysis using all data are reported; however, if re-analysis with outliers removed produced substantively different results, then both analyses are reported.

A

CpAP1

$\mathrm{GA}_{3}$

B

CpAP1

Control

Ethephon

$\mathrm{GA}_{3}$

$2 \mathrm{X} \mathrm{GA}_{3}$

AVG

CpFT

Control

Ethephon

$\mathrm{GA}_{3}$

$2 \mathrm{X} \mathrm{GA}_{3}$

AVG

$C p L F Y$

Control

Ethephon

$\mathrm{GA}_{3}$

$2 \mathrm{X} \mathrm{GA}_{3}$

AVG replicates.

\section{Results and Discussion}

CpLFY EXPREssion. Pecan homologue $C p L F Y$ was more highly expressed in bud tissue than in leaves during both years $(P<0.001)$. Leaf $C p L F Y$ data were not analyzed with the mixed model. A heat map of means highlighting the differences in normalized expression between the bud and leaf tissues for all three genes, $C p A P 1, C p F T$, and $C p L F Y$, was created (Fig. 1). In the control treatment bud tissue, means for normalized gene

Table 3. Unique fluorophores (fluorescent reporter dyes) used to amplify and quantify all four target genes in a single quantitative real-time polymerase chain reaction and their respective excitation and emission wavelengths $(\mathrm{nm})$.

\begin{tabular}{|c|c|c|c|}
\hline Target gene & Fluorophore & Excitation $(\mathrm{nm})$ & Detection $(\mathrm{nm})$ \\
\hline$\overline{C p A C T I N}$ & $\mathrm{HEX}^{\mathrm{TM}}$ & $515-535$ & $560-580$ \\
\hline$C p L F Y$ & 6-FAM & $450-490$ & $515-530$ \\
\hline$C p A P 1$ & Texas Red ${ }^{\mathrm{TM}}$ & $560-590$ & $610-650$ \\
\hline$C p F T$ & $\mathrm{Cy}^{\circledR} 5$ & $620-650$ & $675-690$ \\
\hline
\end{tabular}

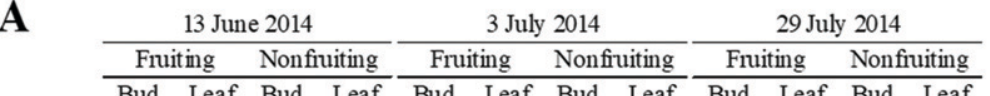

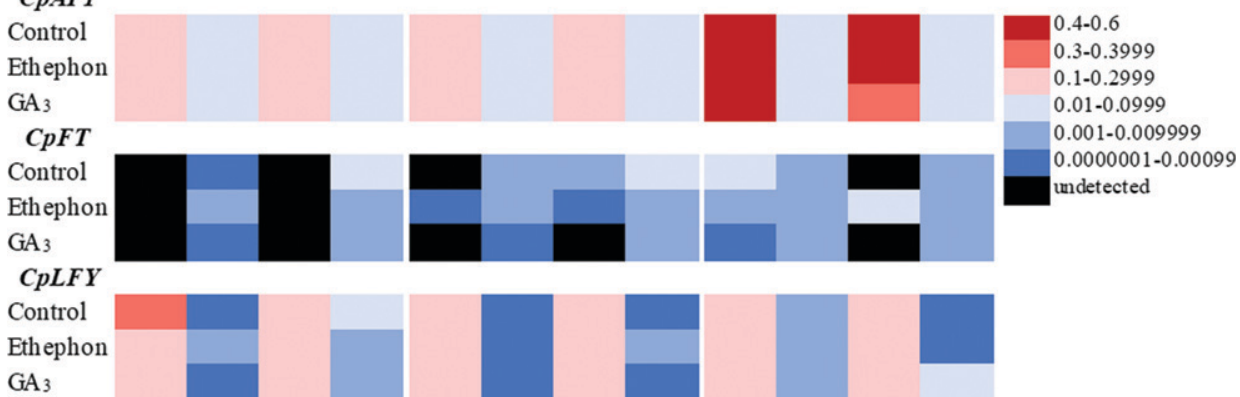

\begin{tabular}{|c|c|c|c|c|c|c|c|c|c|c|}
\hline \multicolumn{4}{|c|}{10 June 2015} & \multicolumn{4}{|c|}{1 July 2015} & \multicolumn{3}{|c|}{23 July 2015} \\
\hline & & Nor & uiting & & ing & Non & uiting & & ting & Nonfruiting \\
\hline$\overline{\mathrm{Bud}}$ & Leaf & $\mathrm{Buc}$ & Leaf & Bud & Leaf & Bud & Leaf & Bud & Leaf & Bud Leaf \\
\hline
\end{tabular}
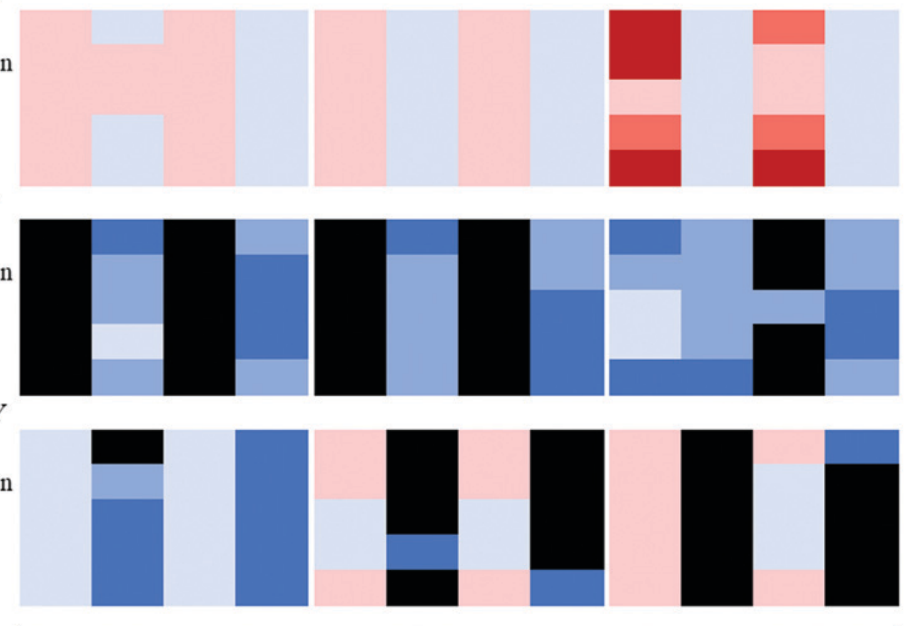

Fig. 1. Heat map representation of mean $C p A P 1, C p F T$, and $C p L F Y$ expression levels on three dates in 2014 (A) and three dates in 2015 (B) in fruiting and nonfruiting bud and leaf tissues treated with plant growth regulator treatments or water (untreated control) $\approx 1$ week before tissue sampling. Means consist of gene expression data from samples analyzed separately from six mature 'Western' pecan trees, each with three technical 
expression across the three sampling dates were $0.23 \pm 0.02$ and $0.11 \pm 0.01$ in 2014 and 2015 , respectively. This $51.4 \%$ decrease in control bud CPLFY expression means from 2014 to 2015 may be related to the annual AB fluctuation in the experimental orchard when 2014 was an "on" year and 2015 was an "off" year. Whether high and low bud $C p L F Y$ expression values are indicators of current season yields or predictors of subsequent season crop load is currently unknown, but it is possible that monitoring $C p L F Y$ expression in bud tissue could be of practical horticultural value to growers.

Expression of $C P L F Y$ in the bud tissues also differed significantly by sampling date during both years (Table 4). Expression levels of $C p L F Y$ on 13 June 2014 were $34.7 \%$ and $31.7 \%$ higher than those on the other two dates during that year, respectively (data not shown). In 2015, the treatment $\times$ date interaction of

Table 4. Probability summary from an analysis of variance for normalized expression of the CpLFY gene in pecan bud tissues from 2014 and 2015. Data from tissues collected on three dates in June and July of each year from fruiting and nonfruiting shoots treated with one of four plant growth regulator treatments or water (untreated control) $\approx 1$ week before tissue sampling. The study was conducted in a mature 'Western' pecan orchard in Las Cruces, NM. Statistical significance was defined in this study as $P \leq 0.05$.

\begin{tabular}{llr}
\hline & \multicolumn{2}{c}{$P$ value } \\
\cline { 2 - 3 } Effect & 2014 & 2015 \\
\hline Shoot fruiting status & 0.430 & 0.097 \\
Sampling date & 0.046 & 0.013 \\
Treatment & 0.533 & $<0.001$ \\
Fruiting status $\times$ date & 0.440 & 0.086 \\
Treatment $\times$ fruiting status & 0.121 & 0.499 \\
Treatment $\times$ date & 0.880 & 0.001 \\
Treatment $\times$ fruiting status $\times$ date & 0.761 & 0.848 \\
\hline
\end{tabular}

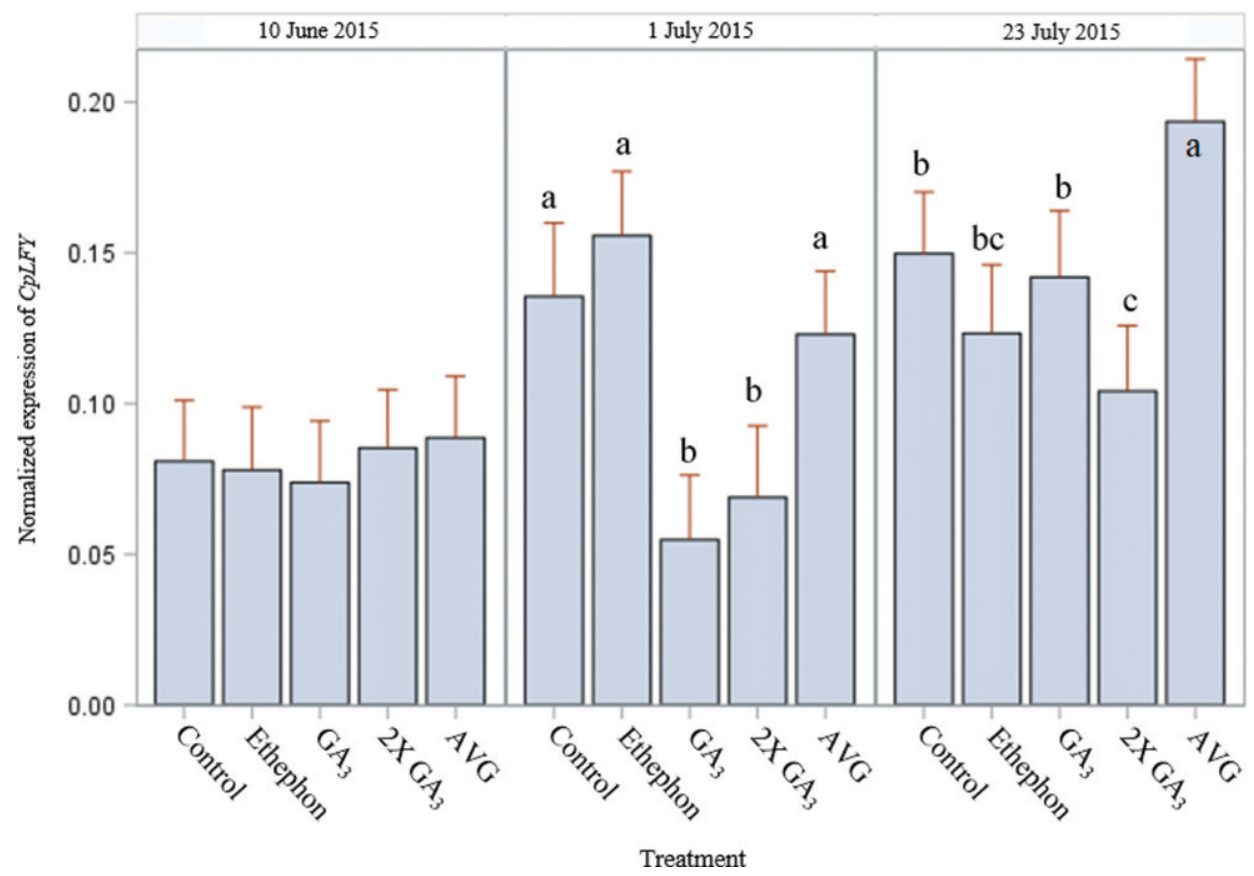

Fig. 2. Date of plant growth regulator treatment least squares means (LSMEANS) for pecan bud tissue $C p L F Y$ normalized expression in 2015. Error bars depict sE. Different lowercase letters represent statistically different LSMEANS within that date $(P \leq 0.05) . \mathrm{GA}_{3}$ and $2 \mathrm{X} \mathrm{GA}_{3}$ correspond to gibberellic acid at single and double rates, respectively, and AVG corresponds to aminoethoxyvinylglycine treatment.
CPLFY expression levels in bud tissues was significant $(P=$ 0.001 ) (Table 4). Compared with the untreated control, a signifiont reduction in bud $C p L F Y$ expression was observed with both 2015 sigs. 1B and 2). Furthermore, on that final June).

CPAP1 EXPREssion. Expression of CpAP1 was significantly hist in bud tissues than tissues $(P<0.001)$, with mean bud $C p A P 1$ expression values of 0.310 and 0.230 and mean leaf $C p A P 1$ expression values of 0.059 and 0.070 in 2014 and 2015, respectively. In 2014 leaf tissues, the date main effect was not statistically significant according to the $C p A P 1$ analysis using all available data

(Table 5, Fig. 1A). After the removal of two outliers (out of 98 total observations), the trend was the same, but differences became significant; the mean normalized CPAP1 expression on 3 July 2014 (0.067) was marginally higher than that on 13 June $2014(0.055)$ and significantly higher than that on 29 July 2014 (0.047). In 2015, the date main effect was significant in leaf tissues; the $C p A P 1$ expression value on 10 June was higher than those on 1 July and 23 July (Fig. 3).

In the buds, the treatment $\times$ date interaction of the expression of $C p A P 1$ was significant in 2014 and in 2015 (Table 5, Figs. 4 and 5). In 2015, a significant fruiting status $\times$ date interaction was detected, with buds from fruiting shoots on the latest date (23 July) expressing $C p A P 1$ at higher rates than those from nonfruiting shoots; again, higher expression rates were observed on the latest date compared with the other two dates (Figs. 1B and 5).

CpFT EXPRESSION. The sign test did not detect a significant difference between leaf and bud $C p F T$ expressions, although a trend was evident between means, with higher $C p F T$ expression levels in leaf compared with bud tissues (Fig. 1). As with $C p L F Y$ in the leaf samples, these low detection level data were not analyzed with the mixed model. A formal analysis of $C p F T$ expressions in leaf and bud tissues across dates or treatments was not practical because of the low detection levels.

For this study, we aimed to examine pecan leaves and buds from PGRtreated fruiting and nonfruiting shoots for expression levels of genes likely to be involved with flowering. This work had not been previously performed for pecan. A major hurdle for the combined study of flowering gene expression and subsequent season return bloom was 
that excising bud tissues is destructive, and return bloom cannot be directly evaluated. Regarding citrus, gene expression analyses showed that although flowering genes were expressed in smaller amounts in leaf than in bud tissues, the expression in leaves mimicked bud expression, thereby making leaf sampling and analysis possible without disrupting subsequent season return bloom in the buds (Muñoz-Fambuena et al., 2012). However, our results suggest that the expression of $C p A P 1$ in the leaf tissues may not mimic activities in the buds, and normalized expressions of $C p L F Y$ and $C p F T$ were too low in leaves or in both leaves and buds to know for certain. Based on the current findings, we cannot recommend that pecan leaf samples should be used to reliably describe flowering gene activity in the buds. Destructive sampling (excising the buds) is recommended for the study of flowering gene expression at this level for pecan, even though return bloom data from sampled tissue cannot be collected during the following season.

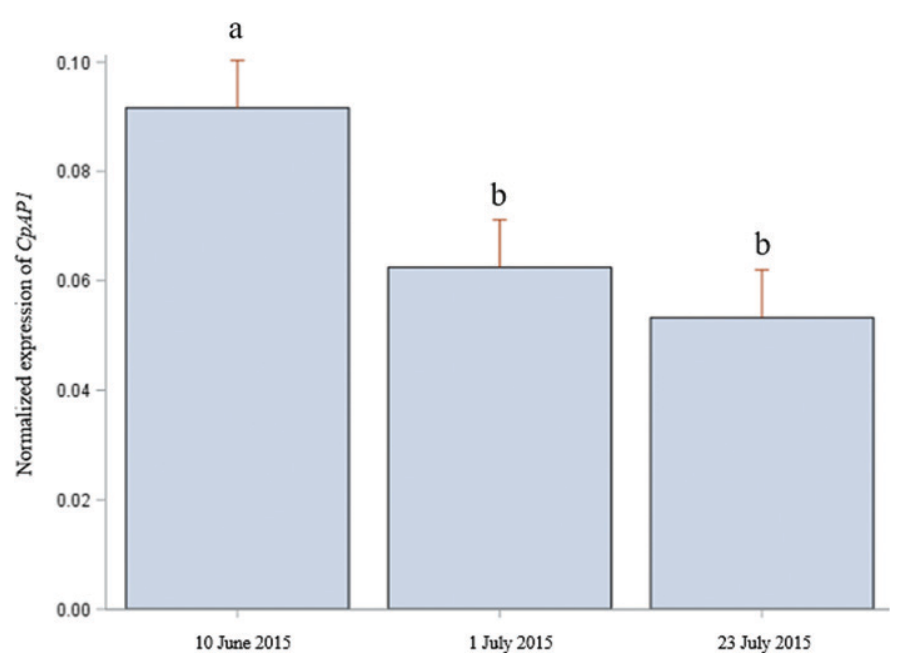

Fig. 3. Date of least squares means (LSMEANS) for normalized gene expression of CpAP1 in pecan leaf tissues in 2015. Error bars depict SE. Different lowercase letters represent statistically different LSMEANS $(P \leq 0.05)$

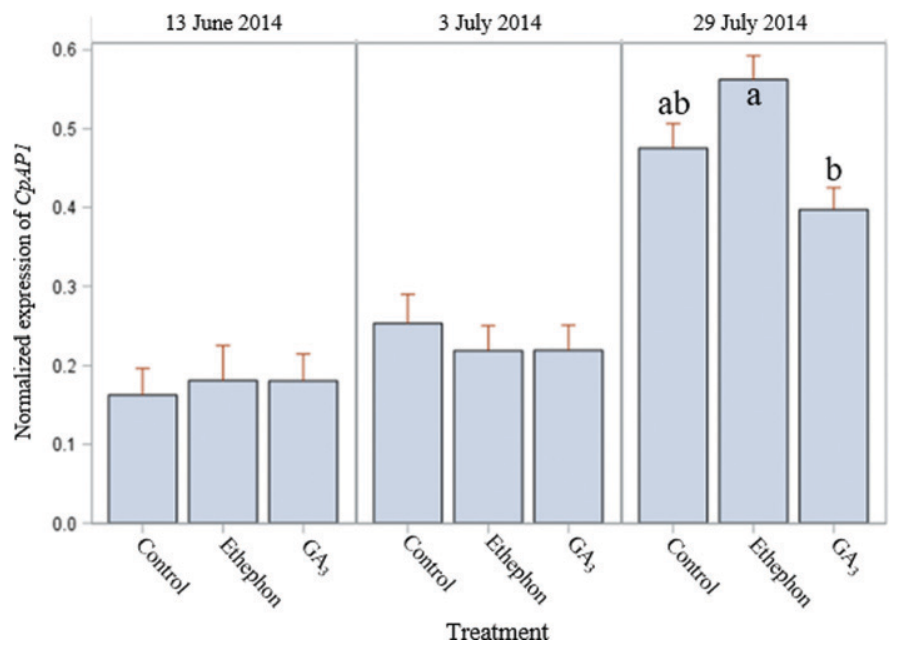

Fig. 4. Date of plant growth regulator treatment least squares means (LSMEANS) for pecan bud tissue $C P A P 1$ normalized expression in 2014. Error bars depict SE. Different lowercase letters represent statistically different LSMEANS within that date $(P \leq 0.05)$.
Differences in the expressions of genes $L F Y$ and $A P 1$ homo$\operatorname{logs}$ based on shoot fruiting status were also found for avocado (Persea americana), but the opposite trend was described; buds from nonfruiting avocado shoots had higher expression levels of both genes than buds from fruiting shoots (Ziv et al., 2014). These differences in outcomes may have occurred because, in that study, the nonfruiting shoots were selected from avocado trees that had been entirely de-fruited earlier in the season. In our study, nonfruiting shoots were selected from trees with fruit. Additionally, avocado flowers are bisexual and pecan flowers are unisexual. The respective genes responsible for staminate and pistillate flower initiation in pecan are not known.

Exogenous treatment involving PGRs on pecan shoots has been shown to affect the return bloom of pistillate flowers in the subsequent season (Thompson et al., 2019; Wood, 2011a, 2011b; Wood et al., 2009). The current study expanded this concept by identifying differences based on PGR treatment of the flowering homologs $C p L F Y$ and $C p A P 1$. Therefore, an argument can be made that these flowering homologs have a role in pistillate flower initiation.

Previously reported promoter analyses of $C p L F Y$ and $C p F T$ indicated that the promoters may have motifs that are likely to be responsive to both phytohormones and the carbohydrate status of pecan (Martin et al., 2015; Randall et al., 2015; Rascon, 2014). This is interesting because of the temporal overlap between early fruit development and floral initiation in trees, like pecan, that are known to initiate flowering during the year before anthesis, because actively growing fruits (and seeds, in particular) inhibit the floral initiation of many deciduous trees, including apple and pear (Monselise and Goldschmidt, 1982).

Regulatory networks in flowering plants that control floral initiation in response to environmental, endogenous, and autonomous signals are known to be complex (Glover, 2008), and pecan is no exception (Amling, 1983; Rohla et al., 2007; Smith et al., 2007; Wood, 2011b). Each pecan bud comprises three inner buds: two lateral staminate inflorescence buds and one central shoot bud that, upon elongation and development of the leaf primordia, either may end in a flower cluster, making it a fruiting shoot, or may not end in a flower cluster, making it a nonfruiting shoot. Therefore, it is assumed that each excised bud, including those in the present study, was likely to have produced staminate flowers, if left intact, and that the detection of gene expression may have been skewed to staminate flower initiation rather than pistillate (Woodroof, 1930). However, separating portions of the compound bud at the time of excision would be too difficult without compromising precious RNA. For other species, it has been shown that the gene network that regulates flowering has more than 180 genes that coordinate floral initiation (Fornara et al., 2010). It is important to note that PGR treatments altered return 
Table 5. Probability summary from the analysis of variance for normalized expression of the CPAPl gene in pecan leaf and bud tissues from 2014 and 2015. Data from tissues collected on three dates in June and July of each year from fruiting and nonfruiting shoots treated with one of four plant growth regulator treatments or water (untreated control) $\approx 1$ week before tissue sampling. The study was conducted in a mature 'Western' pecan orchard in Las Cruces, NM. Statistical significance was defined in this study as $P \leq 0.05$.

\begin{tabular}{llllrr}
\hline & \multicolumn{3}{c}{$P$ value } \\
\cline { 2 - 3 } & \multicolumn{2}{c}{ Leaf tissue } & & \multicolumn{2}{c}{ Bud tissue } \\
\cline { 2 - 3 } \cline { 5 - 6 } Effect & 2014 & 2015 & & 2014 & 2015 \\
\hline Shoot fruiting status & 0.304 & 0.905 & & 0.644 & 0.132 \\
Sampling date & $0.194^{\mathrm{z}}$ & 0.018 & & $<0.001$ & $<0.001$ \\
Treatment & 0.773 & 0.755 & & 0.132 & $0.083^{\mathrm{y}}$ \\
Fruiting status $\times$ date & 0.624 & 0.591 & & 0.293 & 0.016 \\
Treatment $\times$ fruiting status & 0.728 & 0.127 & & 0.721 & 0.181 \\
Treatment $\times$ date & 0.587 & 0.591 & & 0.041 & $<0.001$ \\
Treatment $\times$ fruiting status $\times$ date & 0.361 & 0.790 & & 0.894 & $0.133^{\mathrm{x}}$ \\
\hline${ }^{\mathrm{x}}$ Rem
\end{tabular}

${ }^{\mathrm{z}}$ Removal of two outliers results in $P=0.026$.

${ }^{\mathrm{y}}$ Removal of two outliers results in $P=0.005$.

${ }^{\mathrm{x}}$ Removal of two outliers results in $P=0.025$.

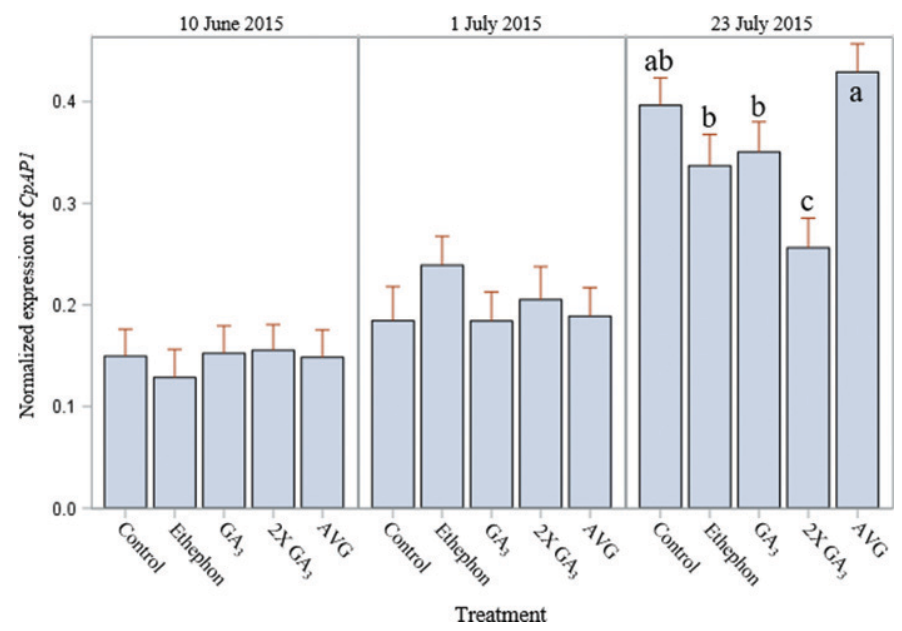

Fig. 5. Date of plant growth regulator treatment least squares means (LSMEANS) for pecan bud tissue CPAP1 normalized expression in 2015. Error bars depict SE. Different lowercase letters represent statistically different LSMEANS within that date $(P \leq 0.05) . \mathrm{GA}_{3}$ and $2 \mathrm{X} \mathrm{GA}_{3}$ correspond to gibberellic acid at single and double rates, respectively, and AVG corresponds to aminoethoxyvinylglycine treatment.

bloom, as described in the parallel study (Thompson et al., 2019), and that the change in return bloom may be correlated to gene expression. The number of flowers per shoot was a return bloom parameter affected by the previous season fruiting status during the second year of the parallel study, and AVG treatment reversed that effect (Thompson et al., 2019). In the current study, gene expression did not appear to differ significantly according to the fruiting status of leaf or bud tissues, regardless of PGR treatment. Thompson et al. (2019) also observed significant treatment effects on the next season return bloom, with $2 \mathrm{X} \mathrm{GA}_{3}$ more than doubling the number of flowers on shoots that were fruiting during the previous year, and all PGR treatments significantly reduced the number of flowers on shoots that were nonfruiting during the previous year. It is possible that $\mathrm{GA}_{3}$ and $2 \mathrm{X} \mathrm{GA}_{3}$ treatment effects lowering $C P L F Y$ expression in bud tissues observed in 2015, or those that lowered $C p A P 1$ expression in 2015 bud tissue, caused the changes in $\mathrm{AB}$ behavior in 2016 that were reported by
Thompson et al. (2019). Perhaps the increased $C p L F Y$ expression in response to AVG treatments affected subsequent season $\mathrm{AB}$ in the parallel study. Further studies involving RNAseq or other technologies are needed to capture the complete picture of genes involved in flowering initiation for subsequent season bloom and how PGR treatments impact the expression of these genes in pecan.

It has been proposed that the initiation of pistillate flowering involves three distinct phases (Wood, 2011b), each with its own trigger for chromatin modification whereby movement of a florigen-like signal (likely FT) via the phloem from the leaf to the SAM is the first phase of floral initiation. Wood (2011b) suggested that phase 2 involves the creation of endogenous phytohormone signals, and that phase three involves sugar signaling at the primordial SAM that responds to vernalization and ends in anthesis after floral development in spring.

One complication involving the molecular study of pecan flowering is that pecan is a monoecious species whose flowers are unisexual, and we do not yet know what genes are responsible for the production of staminate and pistillate flowers. Furthermore, because pecans are heterodichogamous, and because this study was conducted using 'Western' pecan trees, which are protandrous (type 1), it remains to be seen whether similar gene expression patterns may be present in protogynous cultivars. However, because PGRs did have various effects on several return bloom parameters in the related Thompson et al. (2019) study, and because some differences were observed with $C p L F Y$ and $C p A P 1$ based on PGR treatment, the idea that both phytohormones and the expression of these genes have roles in pistillate flower initiation is supported.

In addition to the differences observed with return bloom in response to PGR application (Thompson et al., 2019), our results suggest that the genetic signals for pistillate floral initiation are likely active during the season before anthesis. It is proposed that a multistep decision process dictates pistillate flower initiation in pecan (Fig. 6). In this proposed schematic of the process, floral initiation begins early during the growing season of year 1 (growing season 1), with a new shoot that is either flowering or nonflowering and genetic switches that respond to both environmental (light and temperature) and endogenous signals (including phytohormone production and carbohydrate status), which start a cascade of activity and, eventually, upregulation of flowering gene repressors before and during winter dormancy (middle). Upon spring emergence from dormancy, as budbreak begins, the next phase 


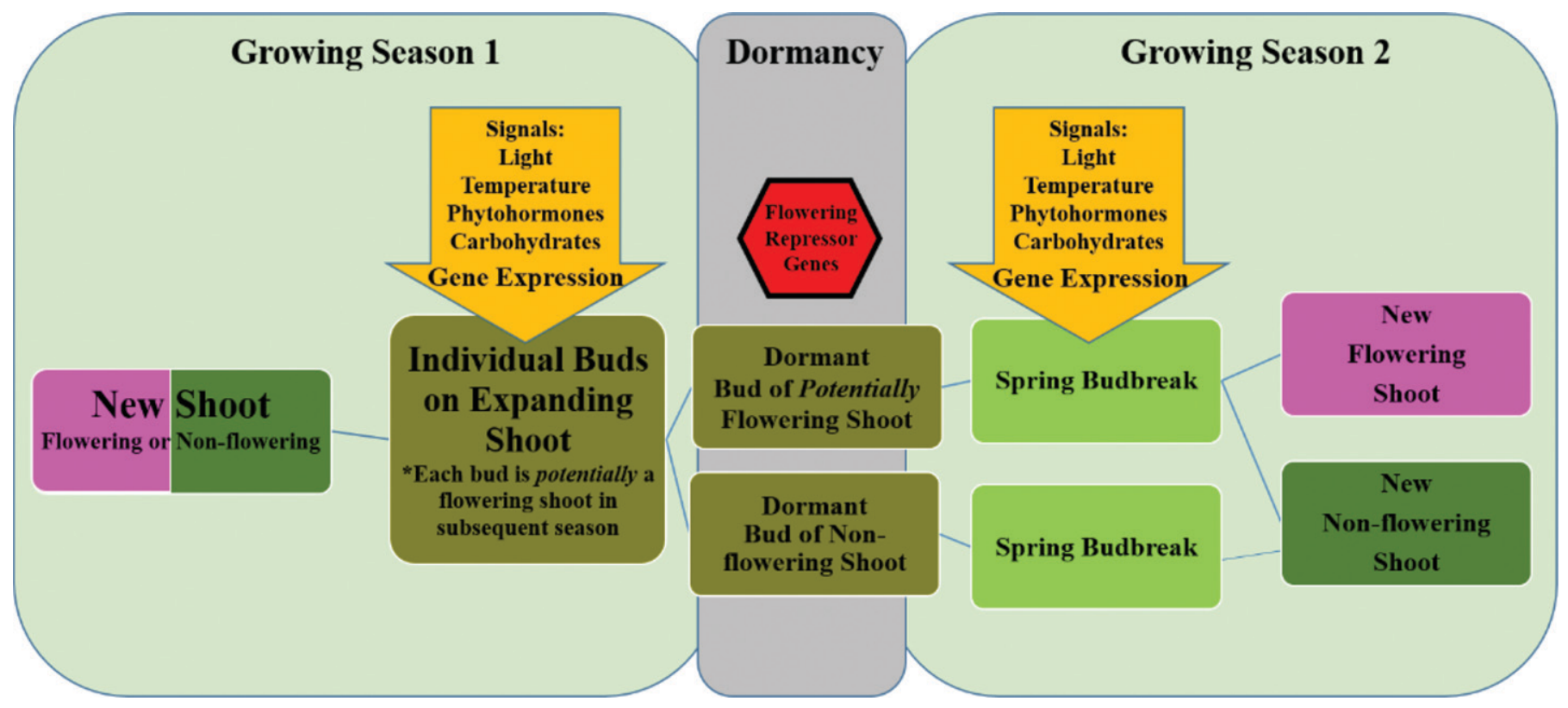

Fig. 6. Proposed schematic of floral initiation process in pecan from new shoot development in growing season 1 (left) through dormancy (middle) to the development of new shoots in growing season 2 (right).

(growing season 2) of the flowering decision process includes those same environmental and endogenous signals that have roles in gene activity (including turning off flowering gene repressors) and the formation of new shoots.

Future work involving the ratios of $C p A P 1$ to $C p L F Y$ in bud tissues from trees with high $\mathrm{AB}$ intensity compared with trees with low $\mathrm{AB}$ intensity may be useful for developing a model for predicting subsequent season crop load. Research of the expression of flowering-related genes in other AB crops, including citrus and apple, points to crop load and associated endogenous phytohormones levels as important regulators of AB (Guitton et al., 2012; Shalom et al., 2012). Plant growth regulators are not yet commonly used at the commercial level for the mitigation of $\mathrm{AB}$ of pecan, although AVG is labeled for use for pecan to increase the fruit and nut set. Gene expression analyses of three homologous genes known to be flowering-related in other species $(C p L F Y, C p A P 1$, and $C p F T)$ provide insights regarding the molecular signals in pecan tissues.

\section{Literature Cited}

Abe, M., Y. Kobayashi, S. Yamamoto, Y. Daimon, A. Yamaguchi, Y. Ikeda, H. Ichinoki, M. Notaguchi, K. Goto, and T. Araki. 2005. FD, a bZIP protein mediating signals from the floral pathway integrator FT at the shoot apex. Science 309:1052-1056, doi: 10.1126/science.1115983.

Amling, H.J. 1983. Floral induction of pecan pistillate flowers. HortScience 18:579.

Amling, H.J. and K.A. Amling. 1983. Physiological differentiation of pistillate flowers of pecan and cold requirements for their initiation. J. Amer. Soc. Hort. Sci. 108:195-198.

An, H., C. Roussot, P. Suárez-López, L. Corbesier, C. Vincent, M. Piñeiro, S. Hepworth, A. Mouradov, S. Justin, C. Turnbull, and G. Coupland. 2004. CONSTANS acts in the phloem to regulate a systemic signal that induces photoperiodic flowering of Arabidopsis. Development 131:3615-3626.

Blázquez, M.A., L.N. Soowal, I. Lee, and D. Weigel. 1997. LEAFY expression and flower initiation in Arabidopsis. Development 124: 3835-3844.
Chan, B.C. and J.C. Cain. 1967. The effect of seed formation on subsequent flowering in apple. Proc. Amer. Soc. Hort. Sci. 91:63-67.

Conner, P.J. and R.E. Worley. 2000. Alternate bearing intensity of pecan cultivars. HortScience 35:1067-1069, doi: 10.21273/ HORTSCI.35.6.1067.

Endo, T., T. Shimada, H. Fujii, Y. Kobayashi, T. Araki, and M. Omura. 2005. Ectopic expression of an FT homolog from citrus confers an early flowering phenotype on trifoliate orange (Poncirus trifoliata L. Raf.). Transgenic Res. 14:703-712, doi: 10.1007/s11248-005-6632-3.

Flachowsky, H., I. Szankowski, S. Waidmann, A. Peil, C. Tranker, and M. Hanke. 2012. The MdTFL1 gene of apple reduces vegetative growth and generation time. Tree Physiol. 32:1288-1301, doi: $10.1093 /$ treephys/tps080.

Fornara, F., A. de Montaigu, and G. Coupland. 2010. SnapShot: Control of flowering in Arabidopsis. Cell 141:550, doi: 10.1016/j. cell.2010.04.024.

Glover, B. 2008. Understanding flowers and flowering: An integrated approach. Oxford Univ. Press, Oxford, UK.

Guitton, B., J.-J. Kelner, R. Velasco, S.E. Gardiner, D. Chagné, and E. Costes. 2012. Genetic control of biennial bearing in apple. J. Expt. Bot. 63:131-149, doi: 10.1093/jxb/err261.

He, Y. and R.M. Amasino. 2005. Role of chromatin modification in flowering-time control. Trends Plant Sci. 10:30-35, doi: 10.1016/j. tplants.2004.11.003.

Herrera, E. 1999. Flowering habits of pecan trees. New Mexico State Univ. Coop. Ext. Serv. Guide H-622. 25 Sept. 2020. <https://aces. nmsu.edu/pubs/_h/H622>.

Hsu, C., J. Adams, H. Kim, K. No, C. Ma, S. Strauss, J. Drnevich, L. Vandervelde, J. Ellis, B. Rice, N. Wickett, L. Gunter, G. Tuskan, A. Brunner, G. Page, A. Barakat, J. Carlson, C. dePamphilis, D. Luthe, and C. Yuceer. 2011. FLOWERING LOCUS T duplication coordinates reproductive and vegetative growth in perennial poplar. Proc. Natl. Acad. Sci. USA 108:10756-10761, doi: 10.1073/pnas.1104713108.

Jenkins, J., B. Wilson, J. Grimwood, J. Schmutz, and L. Grauke. 2015. Towards a reference pecan genome sequence. Acta Hort. 1070:101108, doi: 10.17660/ActaHortic.2015.1070.11.

Kearse, M., R. Moir, A. Wilson, S. Stones-Havas, M. Cheung, S. Sturrock, S. Buxton, A. Cooper, S. Markowitz, C. Duran, T. Thierer, B. Ashton, P. Mentjies, and A. Drummond. 2012. Geneious Basic: An 
integrated and extendable desktop software platform for the organization and analysis of sequence data. Bioinformatics 28:1647-1649.

Kotoda, N.H., H. Hayashi, M. Suzuki, M. Igarashi, Y. Hatsuyama, S. Kidou, T. Igasaki, M. Nishiguchi, K. Yano, T. Shimizu, S. Takahashi, H. Iwanami, S. Moriya, and K. Abe. 2010. Molecular characterization of FLOWERING LOCUS T-like genes of apple (Malus $\times$ domestica Borkh.). Plant Cell Physiol. 51:561-575, doi: 10.1093/ $\mathrm{pcp} / \mathrm{pcq} 021$.

Liu, Y., J. Kong, T. Li, Y. Wang, A. Wang, and Z. Han. 2013. Isolation and characterization of an APETALA1-like gene from pear $(P y-$ rus pyrifolia). Plant Mol. Biol. Rpt. 31:1031-1039, doi: 10.1007/ s11105-012-0540-5.

Martin, J., R. Stamler, and J. Randall. 2015. Elucidating the role FLOWERING LOCUS $T$ plays in pecan flower development. In Vitro Cellular Dev. Biol. Mtg. 51:498-498.

Matsuda, N., K. Ikeda, M. Kurosaka, T. Takashina, K. Isuzugawa, T. Endo, and M. Omura. 2009. Early flowering phenotype in transgenic pears (Pyrus communis L.) expressing the CiFT gene. J. Jpn. Soc. Hort. Sci. 78:410-416, doi: 10.2503/jjshs1.78.410.

Meland, M. and C. Kaiser. 2011. Ethephon as a blossom and fruitlet thinner affects crop load, fruit weight, fruit quality, and return bloom of 'Summerred" apple (Malus × domestica) Borkh. HortScience 46: 432-438, doi: 10.21273/HORTSCI.46.3.432.

Michaels, S.D. and R.M. Amasino. 2000. Memories of winter: Vernalization and the competence to flower. Plant Cell Environ. 23:11451153, doi: 10.1046/j.1365-3040.2000.00643.x.

Mimida, N., S. Kidou, H. Iwanami, S. Moriya, K. Abe, C. Voogd, E. Varkonyi-Gasic, and N. Kotoda. 2011. Apple FLOWERING LOCUS $T$ proteins interact with transcription factors implicated in cell growth and organ development. Tree Physiol. 31:555-566, doi: 10.1093/ treephys/tpr028.

Monselise, S.P. and E.E. Goldschmidt. 1982. Alternate bearing in fruit trees. Hort. Rev. 4:128-173, doi: 10.1002/9781118060773.ch5.

Muñoz-Fambuena, N., C. Mesejo, M.C. Gonzalez-Mas, E. PrimoMillo, M. Agusti, and D. Iglesias. 2012. Fruit load modulates flowering-related gene expression in buds of alternate-bearing 'Moncada' mandarin. Ann. Bot. 110:1109-1118, doi: 10.1093/aob/mcs190.

New Mexico State Climate Center. 2017. Weather stations and data retrieval. 6 Mar. 2017. <https://weather.nmsu.edu/ziamet/request/ station/nmcc-da-3/data/ $>$.

Ramsey, F.L. and D.W. Schafer. 2002. The statistical sleuth, a course in methods of data analysis. 2nd ed. Duxbury Press, Belmont, CA.

Randall, J.J., A. Rascon, R.J. Heerema, and M.T. Potter. 2015. Molecular mechanisms of pecan flower induction. Acta Hort. 1070:89-99, doi: 10.17660/ActaHortic.2015.1070.10.

Rascon, A. 2014. Analysis of $C p L F Y$ in pecan flowering. MS Thesis, New Mexico State Univ., Las Cruces.

Rohla, C.T., M.W. Smith, and N.O. Maness. 2007. A comparison of return bloom and nonstructural carbohydrates, nitrogen, and potassium concentrations in moderate and severe alternate-bearing pecan cultivars. J. Amer. Soc. Hort. Sci. 132:172-177, doi: 10.21273/ JASHS.132.2.172.

Shalom, L., S. Samuels, N. Zur, L. Shlizerman, H. Zemach, M. Weissberg, R. Ophir, E. Blumwald, and A. Sadka. 2012. Alternate bearing in citrus: Changes in the expression of flowering control genes and in global gene expression in ON- versus OFF-crop trees. PLoS One 7:e46930, doi: 10.1371/journal.pone.0046930.

Smith, M.W., C.T. Rohla, and N.O. Maness. 2007. Correlations of cropload and return bloom with root and shoot concentrations of potassium, nitrogen, and nonstructural carbohydrates in pecan. J. Amer. Soc. Hort. Sci. 132:158-165, doi: 10.21273/JASHS.132.1.44.

Takada, S. and K. Goto. 2003. TERMINAL FLOWER2, an Arabidopsis homolog of HETEROCHROMATIN PROTEIN1, counteracts the activation of FLOWERING LOCUS T by CONSTANS in the vascular tissues of leaves to regulate flowering time. Plant Cell 15:28562865, doi: $10.1105 /$ tpc. 016345 .

Thompson, M.Y., J.J. Randall, R.J. Heerema, and D. VanLeeuwen. 2019. Exogenous plant growth regulators show promise for management of alternate bearing in pecan. HortScience 54:1204-1207, doi: 10.21273/HORTSCI13854-18.

Tombesi, S., B.D. Lampinen, S. Metcalf, and T.M. DeJong. 2011. Relationships between spur- and orchard-level fruit bearing in almond (Prunus dulcis). Tree Physiol. 31:1413-1421, doi: 10.1093/treephys/tpr119.

U.S. Department of Agriculture. 2017. Noncitrus fruits and nuts 2017 summary. 24 Sept. 2020. <https://www.nass.usda.gov/Publications/ Todays_Reports/reports/ncit0618.pdf $>$.

Wang, M., D. Xi, Y. Chen, C. Zhu, Y. Zhao, and G. Geng. 2019. Morphological characterization and transcriptome analysis of pistillate flowering in pecan (Carya illinoinensis). Scientia Hort. 257: 108674, doi: 10.1016/j.scienta.2019.108674.

Wang, Z.J., J.Q. Huang, Y.J. Huang, F.F. Chen, and B.S. Zheng. 2012. Cloning and characterization of a homologue of the FLORICAULA/LEAFY gene in hickory (Carya cathayensis Sarg). Plant Mol. Biol. Rpt. 30:794-805, doi: 10.1007/s11105-011-0389-z.

Weinbaum, S.A., T.M. DeJong, and J. Maki. 2001. Reassessment of seed influence on return bloom and fruit growth in 'Bartlett' pear. HortScience 36:295-297, doi: 10.21273/HORTSCI.36.2.295.

Wood, B.W. 1991. Alternate bearing in pecan, p. 180-190. In: B.W. Wood and J.A. Payne (eds.). Pecan husbandry: Challenges and opportunities. First Natl. Pecan Workshop Proc. U.S. Dept. Agr., Agr. Res. Serv., ARS-96.

Wood, B.W. 2003. Pecan production in North America. Southwest. Entomol. Suppl. 27:1-19.

Wood, B.W. 2011a. Influence of aminoethoxyvinylglycine (AVG) on yield and quality of nut crops from a commercial pecan orchard. HortScience 46:586-589, doi: 10.21273/HORTSCI.46.4.586.

Wood, B.W. 2011b. Influence of plant bioregulators on pecan flowering and implications for regulation of pistillate flower initiation. HortScience 46:870-877, doi: 10.21273/HORTSCI.46.6.870.

Wood, B.W., L. Lombardini, and R.J. Heerema. 2009. Influence of aminoethoxyvinylglycine on pecan fruit retention. HortScience 44: 1884-1889, doi: 10.21273/HORTSCI.44.7.1884.

Woodroof, J.G. 1930. Studies of the staminate inflorescence and pollen of Hicoria pecan. J. Agric. Res. 40:1059-1104.

Woodroof, J.G. and N.C. Woodroof. 1926. Fruit-bud differentiation and subsequent development of the flowers in Hicoria pecan. J. Agr. Res. 33:677-685.

Yamaguchi, A., Y. Kobayashi, K. Goto, M. Abe, and T. Araki. 2005. TWIN SISTER OF FT (TSF) acts as a floral pathway integrator redundantly with FT. Plant Cell Physiol. 46:1175-1189, doi: 10.1093/ pcp/pci151.

Ziv, D., T. Zviran, O. Zezak, A. Samach, and V. Irihimovitch. 2014. Expression profiling of FLOWERING LOCUS T-like gene in alternate bearing 'Hass' avocado trees suggests a role for PaFT in avocado flower induction. PLoS One 9:e110613, doi: 10.1371/journal. pone. 0110613 . 